\title{
Anti-NMDA Receptor Encephalitis Occurring after Herpetic Encephalitis in a Child: A Case Report
}

\author{
Khalsi $\mathrm{F}^{1 *}$, Ayari $\mathrm{A}^{1}$, Trabelsi $\mathbf{I}^{1}$, Klaa $\mathrm{H}^{2}$, Turki $\mathbf{I}^{2}$ and Bousetta $\mathrm{K}^{1}$ \\ ${ }^{1}$ Department of Pediatrics, Children's hospital Tunis, Tunisia \\ ${ }^{2}$ Department of Neuropediatric, National Department of Neurology, Tunisia
}

Submission: March 13, 2018; Published: August 31, 2018

*Corresponding author: Khalsi Fatma, Depatment of Pediatrics, Children’s Hospital Tunis, Tunisia, Tel: +21698255935; Email: khalsif@gmail.com

\begin{abstract}
Background: We describe a child with severe generalized choreoathetosis and anti-Nmethyl-D-aspartate receptor encephalitis after herpes simplex virus type 1 encephalitis recent evidence supports an autoimmune trigger for anti-N-methyl-D-aspartate receptor encephalitis following a viral infection.

Patient description: A 7-year-old girl presented with fever and partial seizures and was subsequently treated for proven herpes simplex virus type 1 encephalitis. Shortly thereafter, she developed irritability, orolingual and facial choreodystonic movements, and choreoathetoid movements of her trunk and limbs. Cerebrospinal fluid analysis confirmed anti-N-methyl-D-aspartate receptor antibodies. Management of her movements required titrated doses of clobazam, valproate, tetrabenazine, and immunotherapy. At 3 months' follow-up, her abnormal movements had incompletely resolved.

Conclusion: Our patient adds to recent evidence linking a viral trigger for brain autoimmunity. Movement disorders appear early, leading to early immunothearpy management. Symptomatic treatment for persistent or severe generalized choreodystonic movements is challenging, and no prospective clinical trials are available in the pediatric literature
\end{abstract}

Keywords: Anti-Nmda; Receptor; Encephalitis; Herpetic Encephalitis; Child; Immunothearpy; Choreodystonic; Cerebrospinal

\section{Introduction}

Since its description in children in 2009 [1], encephalitis with antibodies against N-methyl-D- aspartate receptor (NMDAR) that success herpes encephalitis (HE) has entered the mainstream of neurology.It is responsible for clinical worsening that progress from abnormal movements, seizure to a comatose state.

\section{Case Report}

A girl of seven-year-old was brought to emergency department for fever and focal then generalized seizures. She had no remarquable history and her developmental milestones were normal. She was hospitalized, and an initial cranial CT scan was performed and showed cortical and subcortical hypo density involving temporal and parietal lobes and suggesting an herpes encephalitis.

The patient received $20 \mathrm{mg} / \mathrm{kg}$ of phenobarbital because of the recurrence of seizures. The Acyclovir was started with the dose of $500 \mathrm{mg} / \mathrm{m} 2$ thrice a day. Complete blood count and biochemical analysis were normal. A lumbar puncture was performed after the cessation of seizures and revealed a pleocytosis with 310 leucocyte (80\% lymphocyte) and Herpes simplex virus type 1 polymerase chain reaction (PCR) testing was positive in the cerebrospinal fluid (CSF). The cerebral MRI performed three days later revealed the same lesions seen in the CT scan, Acyclovir was maintained for there weeks then the patient was discharged home.

One week later, she was brought by her parents for abnormal movements, anxiety, irritability and a very poor sleep. Physical examination in the first day didn't show any abnormality, two days later the patient become unconscious (Glasgow Coma Scale = 08), deep tendon reflexes were normal. Cerebral MRI didn't show any new cortical lesions neither white matter abnormality. CSF analysis revealed protein and glucose levels of $0.9 \mathrm{~g} / \mathrm{L}$ and $3.05 \mathrm{mmol} / \mathrm{L}$, respectively. On microscopic examination of CSF, fifty leucocyte with $80 \%$ lymphocytes. Herpes PCR testing was negative. CSF sample was positive for autoantibodies Anti-NMDAR seen in the limbic encephalitis. The patient was treated with methylprednisolone $30 \mathrm{mg} / \mathrm{Kg}$, intravenous Immunoglobuline $0.5 \mathrm{~g} / \mathrm{Kg}$ for five days and Acyclovir treatment was reconducted.

After a week of treatment, the patient showed an improvement: Glasgow coma scale improved to 14 and she had 
no longer dysautonomia. Few days later, she developed abnormal and involuntary movements, they were fast, large amplitude and interest limbs, trunk and the neck of the right side of the body. These movements responded to immunoglobulins and tetrabenazine.

At 3 months' followup, her abnormal movements were completely resolved, and she was seizure- free. At 9 months' followup, she has global developmental delay but appears more social and interactive. She is tolerating a slow taper from tetrabenazine, and valproate continues to be her primary antiepileptic therapy.

The outcome was excellent after two years of the diagnostic with minor langage sequaele, the patient returned to school after 10 months and had a good insertion.

Herpes encephalitis is the most common fatal encephalitis [2]. Despite the improvement of prognosis since the advent of the Acyclovir, 35\% of patient still suffer a poor outcome with heavy sequelae or even death. However, symptoms seen during $\mathrm{HE}$ are not resulting only from the direct cytotoxicity of the HSV1. In 2009, Florance NR et al. [1] described anti-NMDAR encephalitis in children and young adolescent then in 2012, Pruss et al. [3], described cases of limbic encephalitis with anti-NMDAR antibodies following an HE. Armangue et al. [4] published a case series in 2014, he concluded that "relapsing post-HE" is often antiNMDAR encephalitis which may occur 1 to 4 weeks after the HE in both adult and children.

It seems that the mechanism for development of anti-NMDAR encephalitis following $\mathrm{HE}$ is probably that the virus induces destruction of the neurons and initiates a primary autoimmune response against NMDAR by presentation of tissue that is normally shielded from systemic immunity [5]. The presence of NMDAR antibodies is not equivalent to the diagnosis of anti-NMDAR encephalitis, a distinct disorder associated with the presence of IgG anti NR1-subunit of the receptor in the CSF [6].
Those antibodies are responsible of psychiatric signs and seizuresinadultsandexplainabnormalmovement(choreoathetosis in $90 \%$ ) and seizures in pediatric population. There is no standard approach for treatment, but it consists generally in a first line immunotherapy and second line immunotherapy. First line immune therapy repose on Intra veinous Immunoglobuline $0.4 \mathrm{~g}$ / $\mathrm{Kg}$ for five days associated with Methylprednisolone $30 \mathrm{mg} / \mathrm{Kg}$. Many studies discuss plasma exchange but it still challenging in pediatric population. If no response after two weeks, Rituximab $(375 \mathrm{mg} / \mathrm{m} 2)$ should be started.

\section{Conclusion}

Finally, the association between NMDAR antibodies and hampered neurocognitive recovery could also have therapeutical implications. Symptoms related to autoimmune reactions are potentially responsive to immune therapy and clinical trials should be designed to find out if the frequency and magnitude of neurocognitive herpetic damage can decrease in the future.

\section{References}

1. Florance NR, Davis RL, Lam C, Szperka C, Zhou L, et al. Anti-NMethyl-D-Aspartate Receptor (NMDAR) Encephalitis in Children and Adolescents. Ann Neurol 66(1): 11-18.

2. Steiner I, Kennedy PG, Pachner AR (2007) The neurotropic herpes viruses: herpes simplex and varicella-zoster. Lancet Neurol 6(11): 1015-1028.

3. Prüss H, Finke C, Höltje M, Hofmann J, Klingbeil C, et al. (2012) N-methylD-aspartate receptor antibodies in herpes simplex encephalitis Ann Neurol 72(6): 902-911.

4. Armangue T, Leypoldt F, Málaga I, Raspall-Chaure M, Marti I, et al. (2014) Herpes simplex virus encephalitis is a trigger of brain autoimmunity. Ann Neurol 75(2): 317-323

5. Dalmau J, Lancaster E, Martinez-Hernandez E, Rosenfeld MR, BaliceGordon R (2011) Clinical experience and laboratory investigations in patients with anti-NMDAR encephalitis. Lancet Neurol 10(1): 63-74.

\section{Your next submission with Juniper Publishers will reach you the below assets}

- Quality Editorial service

- Swift Peer Review

- Reprints availability

- E-prints Service

- Manuscript Podcast for convenient understanding

- Global attainment for your research

- Manuscript accessibility in different formats

( Pdf, E-pub, Full Text, Audio)

- Unceasing customer service

Track the below URL for one-step submission https://juniperpublishers.com/online-submission.php 